\title{
The Effect of the Coffee Roasting Machine on Increasing Production of Arabic Coffee KSM Galuh Lestari Dusun Gunungmalang in Indonesia
}

\author{
Ria Manurung ${ }^{1, *}$ Eko Apriliyanto ${ }^{2}$ Oskar Ika Adi Nugroho $^{1}$ \\ ${ }^{1}$ Sekolah Tinggi Ilmu Komputer Yos Sudarso \\ ${ }^{2}$ Politeknik Banjarnegara \\ *Corresponding author. Email: ria.manurung74@gmail.com
}

\begin{abstract}
The natural potential of Gunungmalang hamlet is in the field of agriculture, especially Arabica coffee. Coffee farmers form an association, namely the Galuh Lestari Community Self-Help Group (KSM), which in roasting Arabica coffee still uses simple equipment in form of drums. Galuh Lestari KSM encounter problems in the coffee processing process, namely (1) the coffee production does not have adequate quality, aroma, and color; (2) it requires a long time to roast coffee and cool the roasted coffee. (3) The minimum number of workers is two; These three problems impact the production of Arabica coffee. KSM Galuh Lestari needed a renewal of the roasting process from manual to modernized roasting machines. The method applied to overcome these problems is the provision of roasting machines with modern technology. The results obtained from this method are (1) Increasing quality and aroma of Arabica coffee; (2) Increasing Arabica Coffee production capacity; (3) Maximum use of 1 labor. It can be concluded that modern roasting machines can provide increased production of KSM Galuh Lestari Gunungmalang Arabica coffee. The economic advantage is increasing demand for roast beans after using modern roasting machines. Before using the roasting device, the average demand for roast bean coffee was $200 \mathrm{~kg} / \mathrm{month}$. After using a modern roasting machine, the need for roast bean coffee is $300 \mathrm{~kg} / \mathrm{month}$. The results of coffee production using a roasting machine result in a significant increase of income for KSM Galuh Lestari. In the marketing sector, the existence of the Gunungmalang e-coffee application has proven to be more effective in reaching broader customers.
\end{abstract}

Keywords: Arabica coffee, Technology, Quality, Labor.

\section{INTRODUCTION}

Coffee is a drink that has many coffee lovers, especially in Indonesian society. 1696 was the arrival year of coffee to the Indonesian archipelago, brought by the VOC from Malabar-India through Java Island. In 1707, coffee seeds began to be distributed to Batavia, Cirebon, the Priangan area, and Java Island until they were successfully cultivated in 1714-1715 [1]. In the 17th century, a Dutch national got the Arabica Mocca coffee beans from Arabia. This type of coffee was also sent by the Dutch governor-general in Malabar to Batavia in 1696. Following floods in 1699, new seeds were brought in and flourished around Jakarta and West Java, eventually spreading to various parts of the
Indonesian archipelago. The cultivation of Arabica coffee experienced a decline in 1876 due to leaf rust disease (hemiplegia vastatrix). Arabica coffee can only survive in high areas (1000 $\mathrm{m}$ and above) where this disease's attack is relatively weak [2].

Whereas in Gunungmalang hamlet, coffee farmers started cultivating coffee in 2010. The geographical location of Gunungmalang hamlet, which is in a mountainous area at an altitude of more than 1,600 masl, makes Gunungmalang coffee farmers only cultivate Arabica coffee. From an economic perspective, the type of coffee that is most in demand is Arabica coffee [3]. 


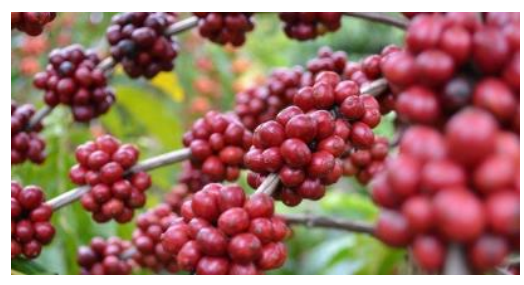

Figure 1 Arabica Coffee Fruits

In 2014, the coffee farmers then formed the Galuh Lestari Community Self-Help Group (KSM), which focuses on the production process of coffee produced by farmers' harvests and focuses on marketing activities for the processed coffee. According to Hariance [4] the production process is an activity carried out to get quality goods or services.

The initial production of Arabica coffee was relatively small because it uses rudimentary equipments, namely, a small steel tube and a gas stove with human power. The tube has a maximum capacity of $1 \mathrm{~kg}$ of Arabica coffee. The use of manual equipment in the processing causes problems for KSM Galuh Lestari, namely: (1) low quality of coffee production, both for the aroma and taste; (2) longer time to roast coffee and cool the roasted coffee with a minimum workforce of 2 people; (3) low production capacity $(1 \mathrm{~kg})$. These three problems have an impact on production yields and the amount of Arabica coffee produced. KSM Galuh Lestari needed a renewal of the roasting process from simple equipment to roasting machines with modern technology. This concurs with research [5], which states that one of the essential processes for obtaining a quality coffee aroma and taste is the coffee roasting process.

The marketing activities of KSM Galuh Lestari coffee products are carried out by word of mouth and door to door so that the scope is minimal. Because of its geographic location, which is at the foot of a mountain, access to the KSM location is difficult. Many people have not seen the existence of Gunungmalang coffee products, which also impacts in the limited reach of the market for product marketing. Based on the above problems, to reach a broader market, technology or application is needed to facilitate marketing activities. The use of technology or applications can make it easier for customers to view the products presented [6].

Based on the above issues, the research problems may be formulated as:

1. How to Improve the Quality of Arabica Coffee production at KSM Galuh Lestari?
2. How is a marketing technology idea expected to help KSM Galuh Lestari in marketing Gunungmalang coffee products?

The purpose of this service activity is to help KSM Galuh Lestari improve the quality of Arabica coffee production and help market products by procuring the Gunungmalang E-Coffee application, which is expected to expand the market reach so that it has an impact on economic improvement in KSM Galuh Lestari Gunungmalang for the future.

\section{RESEARCH METHOD}

1. Procurement of roasting machines with modern technology.

2. Coffee processing using modern roasting machines.

The research method used in this aspect is observation. The observation method is one choice in the data collection stage, namely by observing and recording the research object [7]. In addition to the observation method, in this aspect, the community service team conducted interviews with related partners to find out how much influence modern coffee roasting machines had on improving Arabica coffee production quality at KSM Galuh Lestari.

\section{Marketing}

The method used to solve problems in the marketing sector is to design an Android-based marketing system application, as illustrated in the following design:

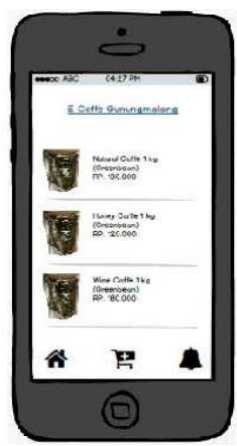

Figure 2 Initial display mockup 


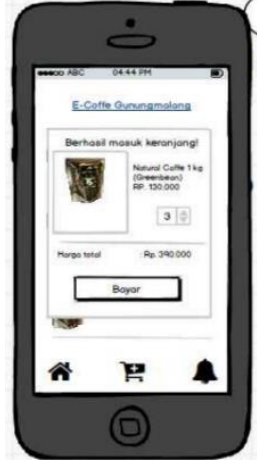

Figure 3 Transaction display mockup

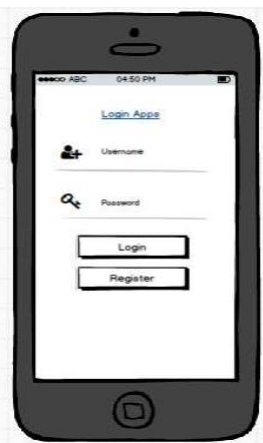

Figure 4 Login display

\section{FINDINGS AND DISCUSSION}

\subsection{The processing of coffee using a modern roasting machine.}

Roasting is the process of roasting coffee beans using high temperatures in an oven or tube up to 200 degrees Celsius [8]. During the roasting process, the fat, sugar, sugarcane, and water content in the coffee beans will change. Along with higher temperatures and moisture loss in the coffee beans, the coffee beans will dry out and then bloom, where the sugar content in the beans will turn into caramel [9].

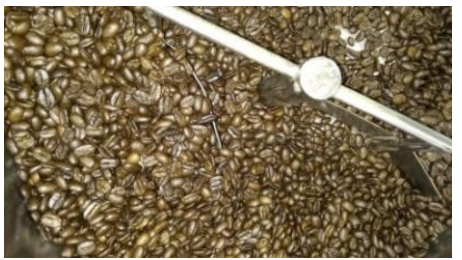

Figure 5 Coffee cooling process after going through the roasting process.

Based on the results of research conducted by Ruwanto [10], the longer the time and the higher the coffee beans' extraction temperature, the more caffeine will be extracted. Using a modern roasting machine proves that three indicators support the improvement of production quality Gunungmalang arabica coffee is as follows:

\subsubsection{Quality Coffee}

Apart from the characteristics of the place where coffee is grown, the processing of coffee after harvest, the use of technology, or roasting methods also play a significant role in influencing the taste and aroma of the coffee produced [8]. The table below compares the quality results of coffee produced before and after using a modern roasting machine.

Table 1. Comparison of Coffee Quality

\begin{tabular}{|c|c|c|c|}
\hline & $\begin{array}{c}\text { Coffee } \\
\text { aroma }\end{array}$ & Taste & $\begin{array}{c}\text { How to } \\
\text { handle } \\
\text { roasting }\end{array}$ \\
\hline $\begin{array}{c}\text { When using } \\
\text { simple } \\
\text { (manual) } \\
\text { equipment }\end{array}$ & $\begin{array}{c}\text { The aroma } \\
\text { of the roast } \\
\text { is less } \\
\text { pronounced }\end{array}$ & $\begin{array}{c}\text { Sour is } \\
\text { close to } \\
\text { bitter }\end{array}$ & $\begin{array}{c}\text { This using } \\
\text { temperatur } \\
\text { e } \\
\text { estimates }\end{array}$ \\
\hline $\begin{array}{c}\text { After using } \\
\text { modern } \\
\text { roasting } \\
\text { machines }\end{array}$ & $\begin{array}{c}\text { More } \\
\text { fragrant and } \\
\text { smelled } \\
\text { more. }\end{array}$ & $\begin{array}{c}\text { Medium } \\
\text { Acid } \\
\text { Level. }\end{array}$ & $\begin{array}{c}\text { Using a } \\
\text { temperatur } \\
\text { e of } 200 \\
\text { degrees } \\
\text { Celsius. }\end{array}$ \\
\hline
\end{tabular}

An increase in the quality of coffee beans that have been roasted using modern roasting machines can be proven by the rise in the amount of roast bean requested by customers and buyers. The following is data on requests or orders for Gunungmalang coffee products from customers and buyers:

Table 2. Customer List and Order Data Before Using Modern Roasting Machines

\begin{tabular}{|c|c|c|c|}
\hline No & $\begin{array}{c}\text { Coffee/ } \\
\text { Roastery Name }\end{array}$ & $\begin{array}{c}\text { Proccess } \\
\text { Type }\end{array}$ & $\begin{array}{c}\text { Average/ } \\
\text { month }\end{array}$ \\
\hline 1 & $\begin{array}{c}\text { WARAK } \\
\text { KOFIE }\end{array}$ & Green bean & $30 \mathrm{Kg}$ \\
\hline 2 & $\begin{array}{c}\text { INLANDER } \\
\text { COFFEE }\end{array}$ & Green bean & $40 \mathrm{Kg}$ \\
\hline 3 & KOPIKALITAS & Green bean & $30 \mathrm{Kg}$ \\
\hline 4 & KOPI OWA & Green bean & $10 \mathrm{Kg}$ \\
\hline 5 & RUMAH KOPI & Green bean & $10 \mathrm{Kg}$ \\
\hline 6 & GOLAGA & Roast bean & $5 \mathrm{Kg}$ \\
\hline
\end{tabular}




\begin{tabular}{|c|c|c|c|}
\hline 7 & $\begin{array}{c}\text { POIN PBG } \\
\text { ROASTERY }\end{array}$ & Green bean & $20 \mathrm{Kg}$ \\
\hline 8 & $\begin{array}{c}\text { Mountaineers / } \\
\text { Other } \\
\text { Customers }\end{array}$ & Coffee Powder & $-+30 \mathrm{Kg}$ \\
\hline 9 & $\begin{array}{c}\text { KILAN. Coffee } \\
\text { \& Eatery }\end{array}$ & Green bean & $10 \mathrm{Kg}$ \\
\hline 10 & $\begin{array}{c}\text { ADVENTURE } \\
\text { COFFEE }\end{array}$ & Green bean & $12 \mathrm{Kg}$ \\
\hline 11 & $\begin{array}{c}\text { KEDAI KOPI } \\
\text { GULO }\end{array}$ & Green bean & $10 \mathrm{Kg}$ \\
\hline 12 & $\begin{array}{c}\text { Kedai Kopi } \\
\text { Pandu Tidar }\end{array}$ & Green bean & $10 \mathrm{Kg}$ \\
\hline 13 & $\begin{array}{c}\text { Praketa Kopi } \\
\text { Aryo }\end{array}$ & $\begin{array}{c}\text { Green bean } \\
\text { Roast bean }\end{array}$ & $12 \mathrm{Kg}$ \\
\hline 15 & Kopi Kebon & Green bean & $13 \mathrm{Kg}$ \\
\hline
\end{tabular}

The table above shows that the average customers still order green beans. Only limited number of customers order the roast beans because of the customer's uncertainty about the roasting process.

After using modern roasting machines, almost all customers who ordered green beans also placed orders on roast beans. The table below shows that customer list after using modern roasting machines.

Table 3. Customer List and Order Data After Using Modern Roasting Machines

\begin{tabular}{|r|l|c|c|}
\hline No & $\begin{array}{l}\text { Coffee/ Roastery } \\
\text { Name }\end{array}$ & $\begin{array}{c}\text { Proccess } \\
\text { Type }\end{array}$ & $\begin{array}{c}\text { Average/ } \\
\text { month }\end{array}$ \\
\hline 1 & WARAK KOFIE & Green bean & $30 \mathrm{Kg}$ \\
\hline 2 & $\begin{array}{l}\text { INLANDER } \\
\text { COFFEE }\end{array}$ & Green bean & $40 \mathrm{Kg}$ \\
\hline 3 & KOPIKALITAS & $\begin{array}{l}\text { Roast bean } \\
\text { Green bean }\end{array}$ & $15 \mathrm{Kg}$ \\
\hline 4 & KOPI OWA & Roast bean & $10 \mathrm{Kg}$ \\
\hline 5 & RUMAH KOPI & Roast bean & $10 \mathrm{Kg}$ \\
\hline 6 & GOLAGA & Roast bean & $5 \mathrm{Kg}$ \\
\hline 7 & $\begin{array}{l}\text { POIN PBG } \\
\text { ROASTERY }\end{array}$ & Roast bean & $20 \mathrm{Kg}$ \\
\hline
\end{tabular}

\begin{tabular}{|r|l|c|c|}
\hline 8 & $\begin{array}{l}\text { Mountaineers / } \\
\text { Other Customers }\end{array}$ & Coffee Powder & $-+30 \mathrm{~kg}$ \\
\hline 9 & Customers Jakarta & Roast bean & $12 \mathrm{Kg}$ \\
\hline 10 & $\begin{array}{l}\text { KILAN. Coffee \& } \\
\text { Eatery }\end{array}$ & Green bean & $10 \mathrm{Kg}$ \\
\hline 11 & $\begin{array}{l}\text { ADVENTURE } \\
\text { COFFEE }\end{array}$ & Roast bean & $12 \mathrm{Kg}$ \\
\hline 12 & $\begin{array}{l}\text { KEDAI KOPI } \\
\text { GULO }\end{array}$ & $\begin{array}{l}\text { Kedai Kopi Pandu } \\
\text { Tidar }\end{array}$ & Roast bean \\
\hline 14 & Praketa Kopi & Green bean & $10 \mathrm{Kg}$ \\
\hline 15 & $\begin{array}{l}\text { Kedai Kopi Den } \\
\text { Aryo }\end{array}$ & Roast bean & $10 \mathrm{Kg}$ \\
\hline 16 & Kopi Kebon & Roast bean & $13 \mathrm{Kg}$ \\
\hline 17 & $\begin{array}{l}\text { Markas Kopi } \\
\text { Petualang }\end{array}$ & Roast bean & $13 \mathrm{Kg}$ \\
\hline 18 & Nekad Coffee & Roast bean & $10 \mathrm{Kg}$ \\
\hline 19 & R Coffee & Roast bean & $10 \mathrm{Kg}$ \\
\hline 20 & Lolana Coffee & Roast bean & $10 \mathrm{Kg}$ \\
\hline
\end{tabular}

From the customer data and orders above, more than $50 \%$ increase in demand for Gunungmalang Arabica coffee roast beans has been recorded after using modern roasting machines.

\subsubsection{Production Capacity and the amount of time it takes to roast coffee.}

The following is a comparison table of production capacity results before and after using a modern roasting machine.

Table 4. Production Capacity and the amount of time it takes to roast coffee

\begin{tabular}{|c|c|c|c|c|}
\hline & $\begin{array}{c}\text { Roasti } \\
\text { ng } \\
\text { Tube } \\
\text { Capaci } \\
\text { ty } \\
\text { (max.). }\end{array}$ & $\begin{array}{c}\text { Amount } \\
\text { of time } \\
\text { for } \\
\text { roasti- } \\
\text { ng. }\end{array}$ & $\begin{array}{c}\text { Amount } \\
\text { of time } \\
\text { to cool } \\
\text { down } \\
\text { the } \\
\text { roast } \\
\text { beans. }\end{array}$ & $\begin{array}{c}\text { Machine/ } \\
\text { technolog } \\
\mathbf{y} \\
\text { capabilit } \\
\mathbf{y}\end{array}$ \\
\hline $\begin{array}{c}\text { Before } \\
\text { using } \\
\text { modern }\end{array}$ & $1 \mathrm{~kg}$ & 30 & $\begin{array}{c}+-30 \\
\text { minutes } \\
\text { (using a } \\
\text { fan and } \\
\text { assisted }\end{array}$ & $\begin{array}{c}\text { Five } \\
\text { times/day } \\
\text { or based } \\
\text { on the } \\
\text { ability of }\end{array}$ \\
\hline
\end{tabular}




\begin{tabular}{|c|c|c|c|c|}
\hline $\begin{array}{c}\text { roasting } \\
\text { machines }\end{array}$ & & & $\begin{array}{c}\text { by } \\
\text { labor). }\end{array}$ & $\begin{array}{c}\text { the } \\
\text { workforce }\end{array}$ \\
\hline $\begin{array}{c}\text { After } \\
\text { using } \\
\text { modern } \\
\text { roasting } \\
\text { machines }\end{array}$ & $5 \mathrm{~kg}$ & $\begin{array}{c}20 \\
\text { minutes }\end{array}$ & $\begin{array}{c}+-20 \\
\text { minutes } \\
\text { (using a } \\
\text { cooling } \\
\text { tube on } \\
\text { a } \\
\text { roasting } \\
\text { machine } \\
\text { ).) }\end{array}$ & No limits \\
\hline
\end{tabular}

Based on the table above, it can be seen that after using a modern roasting machine, the production capacity of packed Gunungmalang Arabica coffee has increased due to the ease of roasting coffee.

\subsubsection{Labor Effectiveness}

Table 5. Use of labor

\begin{tabular}{|l|c|c|c|}
\hline & $\begin{array}{c}\text { Use of } \\
\text { Labor }\end{array}$ & $\begin{array}{c}\text { Total } \\
\text { workforce }\end{array}$ & Information \\
\hline $\begin{array}{l}\text { Before } \\
\text { moding } \\
\text { roasting } \\
\text { machines } \\
\text { the roasting } \\
\text { tube. } \\
\text { b. To spin } \\
\text { the roasting } \\
\text { tube. }\end{array}$ & $\begin{array}{l}\text { To sporsons } \\
\text { Two }\end{array}$ & $\begin{array}{c}\text { Workers must } \\
\text { be on standby } \\
\text { to do the work }\end{array}$ \\
\hline $\begin{array}{l}\text { After } \\
\text { using } \\
\text { modern } \\
\text { roasting } \\
\text { machines }\end{array}$ & $\begin{array}{l}\text { Workforce } \\
\text { only as } \\
\text { operators } \\
\text { of modern } \\
\text { roasting } \\
\text { machines. }\end{array}$ & One & $\begin{array}{c}\text { The worker } \\
\text { can multitask } \\
\text { when roasting } \\
\text { coffee. }\end{array}$ \\
\hline
\end{tabular}

The table above shows that the use of labor after using a modern roasting machine is more effective. The work is relatively light because the workforce is only a machine operator so that in addition to the workforce for operators, it can be transferred to other jobs.

\subsection{Marketing}

The Gunungmalang E-Coffee marketing system application has been made, with a display like this:

\subsubsection{Home Application}

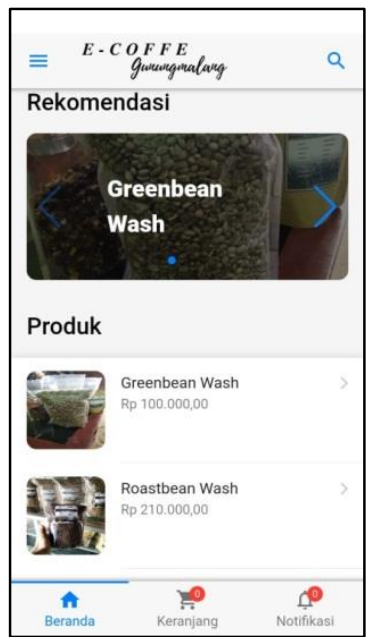

Figure 6 Display Home Application

The home application displays recommendations and Gunungmalang Arabica coffee products.

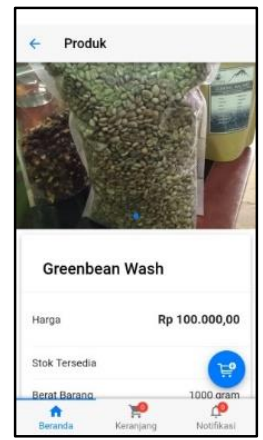

Figure 7 Display Product Application

\subsubsection{Sidebar Application}

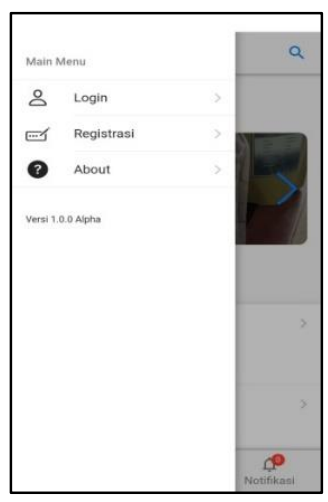

Figure 8 Display Sidebar Application before login

There are menus for login, account registration, and About, which provides detailed information about this application. 


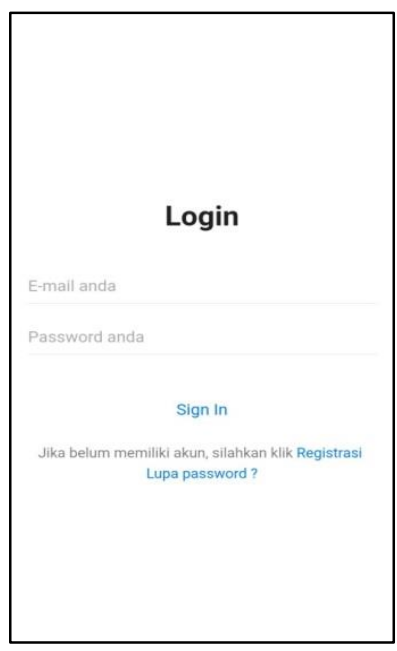

Figure 9 Display Login Application

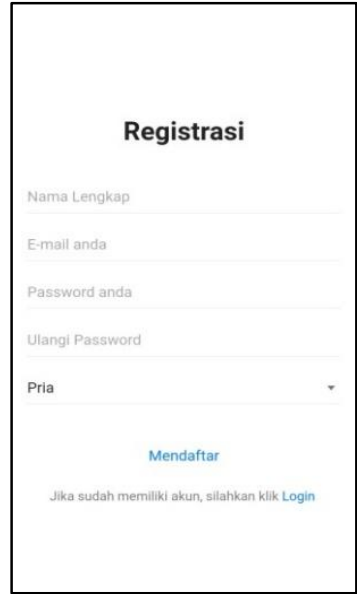

Figure 10 Display Registration Application

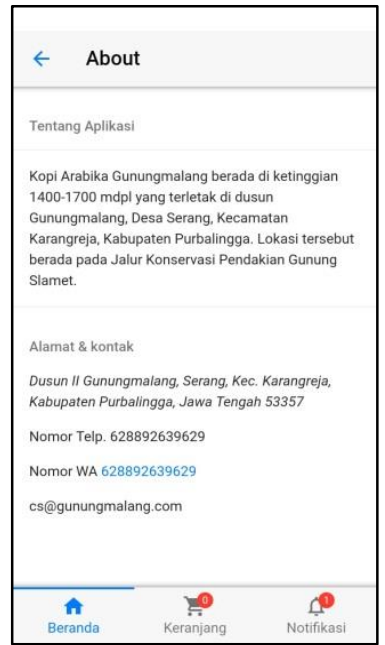

Figure 11 Display About Application

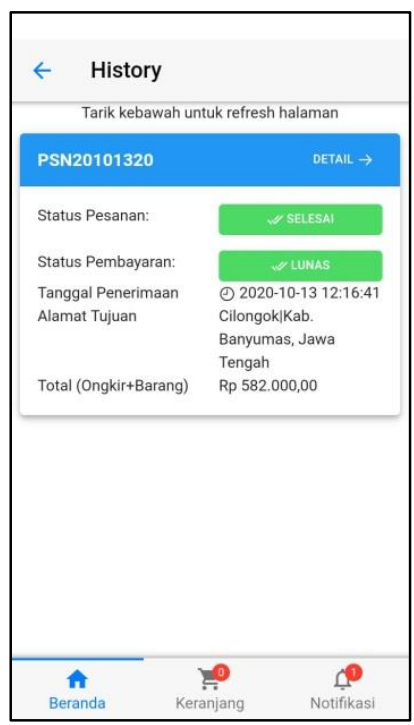

Figure 12 Display History Application

After the user orders a product using this application, the order record will automatically be saved in the history menu.

\subsubsection{Cart}

The cart menu contains products that have been added before checking out the product.

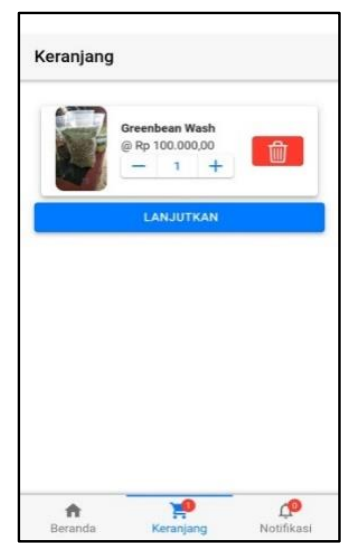

Figure 13 Display Cart

When clicking the continue button, the page will appear as follows: 


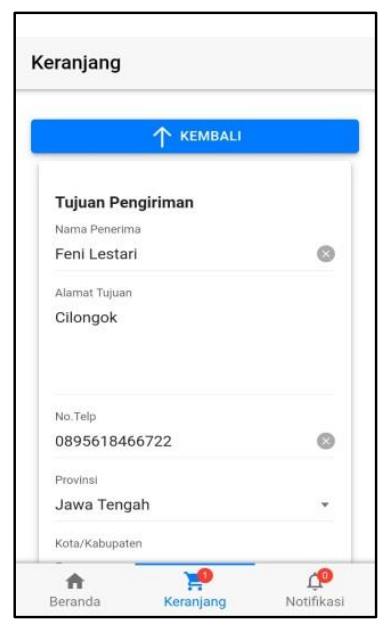

Figure 14 Display Cart (Continued)

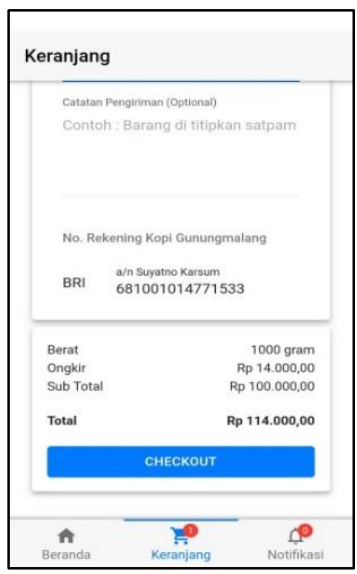

Figure 15 Display Cart (Continued)

\subsubsection{Notification}

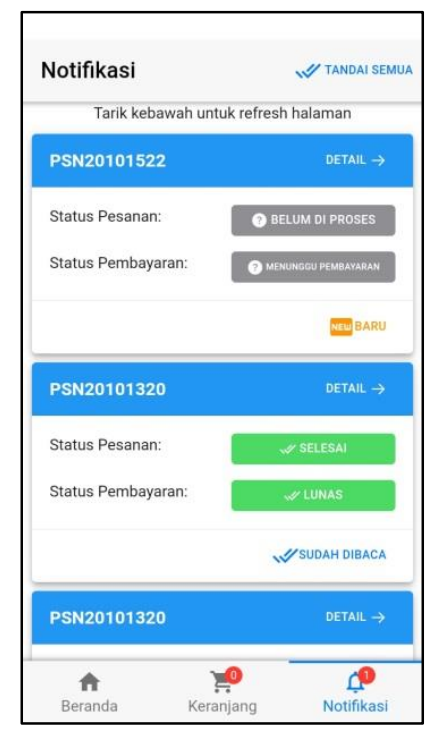

Figure 16 Menu Notification
The notification menu serves to notify customers of all information related to ordering, delivery, and payment.

\section{CONCLUSION}

An activity can conclude that the roasting machine with modern technology helps increase KSM Galuh Lestari Gunungmalang Arabica coffee production, which can be evidenced by differences in production results before and after using technology. After using technology, the quality of coffee products at KSM Galuh Lestari has improved, such as the beans are evenly roasted, and the aroma of coffee is more fragrant. With the existence of coffee roasting technology, the coffee processing process becomes more efficient in terms of labor. The use of two worker is now reduced to a maximum of 1 person. Similarly, the time needed to roast and cool the coffee, which was initially 30 minutes, has been cut to 20 minutes. It can be done simultaneously with the coffee roasting process because the cooling process and the coffee roasting process are done in the same machine.

Furthermore, after using technology, coffee production capacity has increased significantly. The initial production of $2 \mathrm{~kg}$ of roast beans/hour has now increased to $+-10 \mathrm{~kg}$ roast beans/hour. With this machine, KSM Galuh Lestari's income has increased from IDR 20,000,000 / month to IDR $40,000,000 /$ month after using modern roasting machines. This is evidenced by the increasing order of roast bean coffee, which costs IDR 200,000 / kg.

In the marketing sector, the Gunungmalang ecoffee application has proven to be more efficient because it can reach more customers using internet access compared to the process that has been carried out conventionally. This can be seen from the list of customers from various regions, such as Jakarta, Surabaya, and Yogyakarta.

\section{REFERENCES}

[1] C. M. Tucker, Coffee culture: Local experiences, global connections: Second edition. 2017.

[2] O. Ovalle-Rivera, P. Läderach, C. Bunn, M. Obersteiner, and G. Schroth, "Projected shifts in Coffea arabica suitability among major global producing regions due to climate change," PLoS One, 2015, doi: 10.1371/journal.pone.0124155.

[3] A. D. Bote and V. Jan, "Tree management 
and environmental conditions affect coffee (Coffea arabica L.) bean quality," NJAS Wageningen J. Life Sci., 2017, doi: 10.1016/j.njas.2017.09.002.

[4] R. Hariance and R. Febriamansyah, "STRATEGI PENGEMBANGAN AGRIBISNIS KOPI ROBUSTA DI KABUPATEN SOLOK Development Strategy of Robusta Coffee Agribusiness in District of Solok," AGRISEP Maret, 2016.

[5] A. Rahn, S. Smrke, A. Glöss, and C. Yeretzian, "Coffee aroma: essential role of oxidative maillard reaction pathways," ... International Symposium of .... 2018.

[6] J. Järvinen and H. Karjaluoto, "The use of Web analytics for digital marketing performance measurement," Ind. Mark. Manag., 2015, doi: 10.1016/j.indmarman.2015.04.009.

[7] A. Saxena and A. Saxena, "Case study: A Research Method," Voice Intellect. Man- An Int. J., 2019, doi: 10.5958/23194308.2019.00018.5.

[8] N. Liang, W. Xue, P. Kennepohl, and D. D. Kitts, "Interactions between major chlorogenic acid isomers and chemical changes in coffee brew that affect antioxidant activities," Food Chem., 2016, doi: 10.1016/j.foodchem.2016.06.041.

[9] L. F. Ballesteros, M. A. Cerqueira, J. A. Teixeira, and S. I. Mussatto, "Characterization of polysaccharides extracted from spent coffee grounds by alkali pretreatment," Carbohydr. Polym., 2015, doi: 10.1016/j.carbpol.2015.03.047.

[10] Ruwanto, Mursalin, and D. Fortuna, "Pengaruh Tingkat Kematangan Sangrai terhadap Mutu Kopi Libtukom yang Dihasilkan," Prosiding Seminar Nasional FKPT-TPI, 2016. 